\title{
Porównanie francuskich i polskich doświadczeń w zakresie budżetu zadaniowego na przykładzie funkcji Sprawiedliwość ${ }^{1}$
}

\section{Wprowadzenie}

Zastosowanie budżetu zadaniowego w zakresie wymiaru sprawiedliwości i powiązanych z nim dziedzin wywołuje wiele kontrowersji. Szczególnie w pierwszych latach prac wdrożeniowych pomysł ten spotykał się z wieloma zarzutami. Jednak również obecnie zdaniem niektórych budżet zadaniowy stanowi zagrożenie dla niezawisłości sądów lub jest po prostu narzędziem nieprzydatnym w obszarze wymiaru sprawiedliwości i w innych dziedzinach polegających na wykonywaniu uprawnień władczych państwa. Wydaje się jednak, że problem nie tkwi w samym zastosowaniu budżetu zadaniowego w analizowanym obszarze, ale w tym, co jest mierzone i w jakim celu pomiary te są dokonywane.

Budżet zadaniowy jest instrumentem przeniesionym z sektora prywatnych przedsiębiorstw. Sektor prywatny i publiczny realizują jednak odmienne cele. Przedsiębiorstwa nastawione są na osiąganie zysku, natomiast państwo na realizację usług publicznych. Zatem w sektorze publicznym (zarówno na szczeblu państwa, jak i samorządu terytorialnego) pożądanym rezultatem działalności jest efektywność i skuteczność realizacji usług publicznych.

W sektorze prywatnym gospodarka rynkowa, dzięki systemowi ocen w procesie produkcji dóbr prywatnych, jest w stanie osiągnąć efektywną alokację zasobów ${ }^{2}$. Dzięki niewidzialnej ręce konkurencji ${ }^{3}$ na rynku utrzymują się jedynie producenci, którzy w efektywny sposób wytwarzają swoje dobra, których jakość

* Dr Urszula K. Zawadzka-Pąk - Katedra Finansów Publicznych i Prawa Finansowego, Wydział Prawa, Uniwersytet w Białymstoku.

${ }^{1}$ Artykuł powstał w ramach grantu promotorskiego nt. konstrukcji prawnej, wdrażania i realizacji budżetu zadaniowego we Francji i w Polsce realizowanego pod kierunkiem prof. zw. dr. hab. Eugeniusza Ruśkowskiego (N N110 189240).

2 J. E. Stiglitz, Ekonomia sektora publicznego, Warszawa 2004, s. 184-185.

3 A. Smith, Badania nad natura i przyczynami bogactwa narodów, Warszawa 2008. 
i cena są w stanie przekonać potencjalnych klientów o zakupie danych towarów, a zatem utrzymują się tylko przedsiębiorstwa przynoszące zysk.

Z oczywistych względów do oceny funkcjonowania państwa nie można zastosować kryterium zysku, konieczne zatem staje się zastosowanie innych kryteriów. W tym celu wykorzystywane są różnego rodzaju mierniki. Wybór takich mierników, które by w satysfakcjonującym stopniu mierzyły efekty działalności sektora publicznego, napotyka na trudności we wszystkich krajach, gdzie wdrażany jest budżet zadaniowy. Przestrzeganie międzynarodowych standardów opracowywania mierników oraz wzorowanie się na doświadczeniach zagranicznych jedynie częściowo mogą usprawnić proces ich doskonalenia ze względu na specyfikę poszczególnych państw. Mankamenty związane z konstrukcją mierników są stopniowo likwidowane, jednak nawet w krajach, w których budżetowanie zadaniowe stosowane jest od wielu lat, około 10\% mierników jest nadal niepoprawnych. Zadowalający poziom pomiaru rezultatów najtrudniej jest uzyskać w dziedzinach o charakterze typowo władczym (taki charakter mają m.in. uprawnienia związane z wymiarem sprawiedliwości), gdzie realizowane zadania nie mają charakteru typowych usług publicznych.

\section{Konstrukcja prawna budżetu zadaniowego}

W Polsce budżet zadaniowy opiera się na trzech filarach. Pierwszym z nich jest układ zadaniowy wydatków zamieszczany w uzasadnieniu do ustawy budżetowej (II i III tom). Po wykonaniu budżetu w układzie tradycyjnym (który jako jedyny ma wiążący charakter) opracowywana jest informacja o wykonaniu wydatków w układzie zadaniowym. Drugim filarem budżetu zadaniowego są programy wieloletnie, których zestawienie jest zamieszczane w załączniku do ustawy budżetowej. Trzecim zaś filarem jest Wieloletni Plan Finansowy Państwa (dalej: WPFP) zawierający m.in. wydatki budżetu państwa w układzie funkcji (łącznie z celami i miernikami) na okres czterech lat. Corocznie opracowywana jest też informacja $\mathrm{z}$ realizacji WPFP.

Inaczej sytuacja wygląda we Francji, gdzie budżet tradycyjny został całkowicie zastąpiony budżetem zadaniowym. W ustawie finansowej (budżetowej) zamieszczane są limity wydatków dla zadań wchodzących w skład poszczególnych funkcji. Limity te są dwojakiego rodzaju - ustala się upoważnienia do zaciągania zobowiązań oraz środki na płatności. W ustawie finansowej ustalany jest dodatkowo podlimit wydatków tytułu 2. (wydatki na wynagrodzenia). Szczegółowy podział wydatków zadań na pozostałe tytuły (o charakterze szacunkowym) jest zamieszczany w załącznikach do ustawy finansowej, w tzw. rocznych planach rezultatów (fr. projet annuel de performance - PAP). Te dokumenty o charakterze planistycznym zawierają także tzw. część sprawnościową budżetu zadaniowego, tj. cele i mierniki. W ustawach zatwierdzających wykonanie budżetu 
(fr. loi de règlement) zamieszczana jest informacja o zrealizowanych wydatkach. Natomiast informacja o realizacji celów i mierników umieszczana jest w załącznikach do tej ustawy zatwierdzającej, tzw. rocznych raportach rezultatów (fr. rapport annuel de performance - RAP), które mają analogiczną strukturę jak dokumenty o charakterze planistycznym PAP, dzięki czemu możliwe jest porównywanie planowanych i realizowanych rezultatów. Roczne planowanie (programowanie) zadaniowe jest spójne $\mathrm{z}$ programowaniem wieloletnim realizowanym przez ustawy o programowaniu finansów publicznych, o czym poniżej.

\section{Klasyfikacja zadaniowa}

Układ zadaniowy wydatków we Francji i w Polsce jest bardzo zbliżony ze względu na fakt, że model francuski stał się punktem wyjścia dla rozwiązań przyjętych w Polsce. Francuska klasyfikacja zadaniowa składa się z missions, programmes i actions, natomiast polski układ zadaniowy wydatków z funkcji, zadań i podzadań. Ze względu na fakt, że rozwiązania francuskie stały się wzorem dla układu zadaniowego wydatków przyjętego w Polsce, za uprawnione należy uznać thumaczenie terminów określających francuską strukturę zadaniową przy wykorzystaniu nazewnictwa stosowanego w Polsce (tj. funkcja, zadanie i podzadanie). Takie rozwiązanie ma również walor praktyczny, gdyż ułatwi porównywanie francuskich i polskich rozwiązań.

Analiza porównawcza francuskiego i polskiego budżetu zadaniowego (dość ograniczona ze względu na rozmiar niniejszego opracowania) zostanie dokonana na przykładzie funkcji 18. polskiego budżetu zadaniowego (Sprawiedliwość) oraz najbardziej zbliżonej do niej treściowo funkcji francuskiego budżetu zadaniowego (fr. Justice), którą można przetłumaczyć również jako Sprawiedliwośćt . Aby uniknąć wątpliwości, czy omawiane zagadnienia dotyczą francuskiej czy też polskiej funkcji, w stosunku do funkcji francuskiej stosować będziemy jej oryginalną nazwę (fr. Justice). Analiz dokonano w oparciu o materiały planistyczne i sprawozdania z wykonania budżetu zadaniowego za $2011 \mathrm{r}$.

Funkcja Justice obejmuje pięć zadań realizowanych przez Ministerstwo Sprawiedliwości, które są niezbędne do zapewnienia jedności państwa, tj. sądownictwo cywilne i karne, przygotowywanie ustaw i rozporządzeń, wyznaczanie kierunków polityki penalnej i wykonywania kar, środków wychowawczych oraz pomoc postpenitencjarną ${ }^{5}$. Natomiast na funkcję 18. Sprawiedliwość składa się sześć zadań obejmujących sprawy sądownictwa, wykonywania kar, środków wychowawczych oraz środka poprawczego orzeczonego przez sądy, a także spra-

${ }^{4}$ We francuskim budżecie zadaniowym, inaczej niż w Polsce, funkcje nie są numerowane, lecz omawiane w kolejności alfabetycznej.

${ }^{5}$ Projet annuel de performance (PAP). Justice, 2011, s. 10, www.performance-publique.budget.gouv.fr. 
wy pomocy postpenitencjarnej. W omawianym zakresie finansowane jest m.in. podnoszenie jakości administracyjnej działalności sądów, zapewnienie im odpowiednich warunków lokalowych, a także utrzymanie i rozwój istniejącej infrastruktury informatycznej ${ }^{6}$. Środkami tej funkcji dysponuje minister sprawiedliwości (któremu powierzono zdecydowaną większość środków przypisanych do tej funkcji), a także minister obrony narodowej, Naczelny Sąd Administracyjny oraz Krajowa Rada Sądownictwa. Poniższa tabela prezentuje zadania składające się na funkcję Sprawiedliwość oraz funkcję Justice.

Tabela 1. Struktura polskiej funkcji Sprawiedliwość oraz francuskiej Justice

\begin{tabular}{|l|l|}
\hline \multicolumn{1}{|c|}{$\begin{array}{c}\text { Zadania funkcji Sprawiedliwość } \\
\text { w polskim budżecie zadaniowym }\end{array}$} & \multicolumn{1}{c|}{$\begin{array}{c}\text { Zadania funkcji Justice } \\
\text { we francuskim budżecie zadaniowym }\end{array}$} \\
\hline $\begin{array}{l}\text { Zadanie 18.1. Sprawowanie wymiaru sprawie- } \\
\text { dliwości przez sądy powszechne i wojskowe }\end{array}$ & Zadanie 166. Sądownictwo (cywilne i karne) \\
\hline $\begin{array}{l}\text { Zadanie 18.2. Sprawowanie wymiaru sprawie- } \\
\text { dliwości przez sądownictwo administracyjne }\end{array}$ & $\begin{array}{l}\text { Zadanie 310. Realizacja i koordynacja polityki } \\
\text { wymiaru sprawiedliwości }\end{array}$ \\
\hline $\begin{array}{l}\text { Zadanie 18.3. Sprawowanie wymiaru sprawie- } \\
\text { dliwości przez Sąd Najwyższy oraz działalność } \\
\text { Krajowej Rady Sądownictwa }\end{array}$ & $\begin{array}{l}\text { Zadanie 101. Dostęp do wymiaru sprawiedli- } \\
\text { wości }\end{array}$ \\
\hline $\begin{array}{l}\text { Zadanie 18.4. Wykonywanie kary pozbawienia } \\
\text { wolności i tymczasowego aresztowania }\end{array}$ & Zadanie 107. Administracja penitencjarna \\
\hline $\begin{array}{l}\text { Zadanie 18.5. Przeciwdziałanie demoralizacji } \\
\text { i przestępczości wśród nieletnich i stworzenie } \\
\text { warunków do powrotu nieletnich do normalne- } \\
\text { go życia }\end{array}$ & Zadanie 182. Sądowa ochrona nieletnich \\
\hline $\begin{array}{l}\text { Zadanie 18.6. Informatyzacja działalności } \\
\text { i budowa społeczeństwa informacyjnego }\end{array}$ & \\
\hline
\end{tabular}

Źródło: opracowanie własne.

Jak wynika z powyższej tabeli, analizowane funkcje budżetu zadaniowego we Francji i w Polsce, pomimo zbieżności nazewnictwa, mają nieco inny zakres przedmiotowy. Wynika to m.in. z faktu, że wydatki przeznaczone na sądownictwo administracyjne we Francji są wpisane do funkcji Conseil et Contrôle d'Etat (obejmującej wydatki Rady Państwa i innych sądów administracyjnych, Rady ds. gospodarczych, społecznych i ochrony środowiska, Trybunału Obrachunkowego oraz regionalnych izb obrachunkowych), a wydatki na finansowanie sądownictwa wojskowego (fr. Tribunal aux armées de Paris) przypisane zostały do zadania wsparcie polityki obrony, należącego do funkcji Obrona Narodowa (fr. Défense). Natomiast treściowo zbliżony charakter mają: polskie zadanie 18.1. Sprawowanie wymiaru sprawiedliwości przez sądy powszechne i wojskowe (z wyłączeniem sądownictwa wojskowego, o czym wspomniano powyżej) oraz francuskie zadanie 166. Sądownictwo. Przedmiotowo pokrywają się w pewnym przybliżeniu

${ }^{6}$ Uzasadnienia do ustawy budżetowej na 2011 r., t. II, s. 191. 
także: polskie zadanie 18.4. Wykonywanie kary pozbawienia wolności i tymczasowego aresztowania oraz francuskie zadanie 107. Administracja penitencjarna, a także polskie zadanie 18.5. Przeciwdziałanie demoralizacji i przestępczości wśród nieletnich i stworzenie warunków do powrotu nieletnich do normalnego życia oraz francuskie zadanie 182. Sądowa ochrona nieletnich.

Analiza zarówno struktury funkcji Sprawiedliwość i Justice, jak i innych funkcji francuskiego i polskiego budżetu zadaniowego prowadzi do wniosku, że w zależności od przyjętej koncepcji możliwe jest różne przyporządkowanie realizowanych zadań do poszczególnych funkcji.

\section{Powiązanie budżetu zadaniowego z planowaniem (programowaniem) wieloletnim wydatków i strategiczną refleksją nad funkcjonowaniem państwa}

Zarówno w Polsce, jak i we Francji roczne planowanie zadaniowe wpisuje się w wieloletnie planowanie (programowanie) wydatków.

Tom II uzasadnienia do ustawy budżetowej jest powiązany z wieloletnim planowaniem wydatków poprzez wskazanie w WPFP limitów wydatków ustalonych dla poszczególnych funkcji. Powiązanie WPFP z uzasadnieniem wydatków w układzie zadaniowym wynika również z odwołania w II tomie uzasadnienia do strategicznych celów i mierników zamieszczonych w WPFP. Są one następnie przekładane na cele operacyjne (i odpowiadające im mierniki) w dalszej części tomu II oraz w tomie III uzasadnienia. Na poziomie funkcji cele (i odpowiadające im mierniki) ustalane są w WPFP, zaś w uzasadnieniu do ustawy budżetowej (tom II) są jedynie powtarzane.

W Wieloletnim Planie Finansowym Państwa na lata 2010-2013 na poziomie funkcji Sprawiedliwość określono dwa cele. Stopień realizacji pierwszego z nich (zagwarantowanie obywatelom konstytucyjnego prawa do sądu) mierzony jest za pomocą dwóch mierników: odsetek obywateli pozytywnie oceniających pracę sądów oraz odsetek spraw, w których uwzględniono skargi na naruszenie prawa strony do rozpoznania sprawy w postępowaniu sądowym bez nieuzasadnionej zwłoki. Drugim celem strategicznym analizowanej funkcji ustalonym w WPFP jest zapewnienie bezpieczeństwa społecznego poprzez izolację osób tymczasowo aresztowanych i skazanych na karę pozbawienia wolności oraz resocjalizację wychowanków zakładów poprawczych i schronisk dla nieletnich. Poziom realizacji tego celu mierzony jest także za pomocą dwóch mierników (odsetek zaludnienia w zakładach karnych i aresztach śledczych oraz powrotność wychowanków zakładów poprawczych na drogę przestępstwa) ${ }^{7}$.

${ }^{7}$ Uchwała nr 36 Rady Ministrów z 5 kwietnia 2011 r. w sprawie aktualizacji Wieloletniego Planu Finansowego Państwa na lata 2011-2014 (M.P. z 2011 r. Nr 29, poz. 324). 
We Francji powiązanie planowania rocznego z planowaniem wieloletnim następuje, podobnie jak w Polsce, poprzez odwołanie w rocznych planach rezultatów do ustalonych w ustawie o programowaniu finansów publicznych limitów wydatków (upoważnień do zaciągania zobowiązań i środków na płatności) na poziomie poszczególnych funkcji państwa. Ustawy o programowaniu finansów publicznych, inaczej niż WPFP w Polsce, nie zawierają strategicznych celów i mierników, które we Francji zamieszczane są na początku załączników do ustawy finansowej o charakterze planistycznym PAP. Dokumenty te wpisują się zatem w szerszą refleksję strategiczną nad realizacją poszczególnych polityk państwa. Wynika to $\mathrm{z}$ faktu, że francuski budżet zadaniowy jest bardzo ściśle powiązany ze strategiczną, całościową refleksją nad funkcjonowaniem poszczególnych obszarów państwa i reformami zaplanowanymi w wyniku zakrojonego na szeroką skalę Całościowego Przeglądu Polityk Publicznych (fr. Révision générale des politiques publiques $\left.-\mathrm{RGPP}^{8}\right)$. $\mathrm{Z}$ tego powodu roczne plany rezultatów PAP poszczególnych funkcji państwa zawierają syntetyczne omówienie reform (wykraczających poza okres jednego roku budżetowego), których przeprowadzenie ma przyczynić się do realizacji celów danej funkcji.

W rocznym projekcie rezultatów funkcji Justice, stanowiącym załącznik do ustawy finansowej (budżetowej) na 2011 r., określono podstawowe cele reform, które poprzez unowocześnienie organizacji i metod pracy mają przyczynić się do zwiększenia skuteczności i efektywności funkcjonowania wymiaru sprawiedliwości. Zamierzenia te mają zostać dokonane dzięki uproszczeniu wymaganych dokumentów oraz częściowej dematerializacji procedur. Zaplanowana została także racjonalizacja i uproszczenie systemu pomocy sądowej, by zmniejszyć koszt jej funkcjonowania. Działania te mają prowadzić do ograniczenia wydatków bieżących - w 2011 r. zaplanowano ich zmniejszenie o $100 \mathrm{mln}$ euro przy planowanym wzroście zatrudnienia o 400 ekwiwalentu pełnego przepracowanego etatu (ETPT).

W ramach funkcji Justice zaplanowano również w 2011 r. wydatki inwestycyjne, jak np. budowę Pałacu Sprawiedliwości (w formie partnerstwa publicznego-prywatnego), który będzie siedzibą paryskiego sądu pierwszej instancji. Za priorytet uznano również stopniową modernizację więzień. Do 2017 r. zostanie zamkniętych 9 tys. najbardziej zniszczonych miejsc, w zamian za co zostanie otwartych 14 tys. nowych, które będą mieściły się w ponad 20 nowych budynkach i których położenie oraz struktura mają ułatwić powrót więźniów do normalnego życia oraz zapobiegać zjawisku recydywy. Realizacja tych zamierzeń spowoduje, że Francja będzie dysponować 68 tys. miejsc dla więźniów, z czego ponad połowa została otwarta po $1990 \mathrm{r}$.

${ }^{8}$ E. Ruśkowski, U. K. Zawadzka-Pąk (red.), Prawne problemy konstrukcji prawnej i funkcjonowania budżetu zadaniowego we Francji. Wnioski dla Polski, Białystok 2010, s. 67-72. 
Informacja o realizacji zaplanowanych $\mathrm{w}$ dokumentach PAP rezultatach jest zamieszczana w rocznych raportach rezultatów (RAP) ${ }^{9}$, które stanowią rodzaj sprawozdania z realizacji osiągniętych efektów i zaplanowanych reform wynikających ze strategicznej refleksji nad funkcjonowaniem państwa, dokonanej w ramach Całościowego Przeglądu Polityk Publicznych (RGPP). Dokumenty RAP zawierają zarówno syntetyczną informację dotyczącą celów priorytetowych całej funkcji, jak i rezultaty uzyskane w wyniku realizacji jej poszczególnych zadań. Przykładowo, jednym z celów realizacji zadania Administracja penitencjarna jest zmniejszanie zjawiska recydywy. W dokumencie RAP dla funkcji Justice wskazano konkretne działania, które podjęto w tym celu. Polegały one m.in. na podpisaniu trzyletniej umowy z agencją ds. walki z analfabetyzmem w celu realizacji programów z osobami przebywającymi w więzieniach oraz w zakładach poprawczych. Wydane zostało także wspólne rozporządzenie przez ministra sprawiedliwości i ministra edukacji narodowej w celu dostosowania programów nauczania do zmian dokonanych w ustawie o więziennictwie. Podpisano także ramowy protokół pomiędzy ministrem sprawiedliwości i ministrem kultury w celu zagwarantowania jakości, różnorodności i ciągłości propozycji aktywności kulturalnych dla tych osób. Zawarto także porozumienie z pracodawcami, które zwiększa szanse na zatrudnienie byłych więźniów w przemyśle. W sprawozdaniu wskazano też, iż dobiegają końca prace nad tekstem okólnika dotyczącego kształcenia zawodowego więźniów oraz nad przewodnikiem, którego publikacja ma ułatwić zawieranie umów ze stowarzyszeniami.

\section{Analiza wybranych mierników}

Analiza mierników polskiej i francuskiej funkcji Sprawiedliwość prowadzi do wniosku, iż w Polsce przeważają mierniki produktu. Są nimi m.in. miernik zadania 18.3. Liczba sędziów Sądu Najwyższego oraz miernik realizacji zadania 18.4. Liczba skazanych objętych systemem programowego oddziaływania. Charakter produktowy mają także mierniki zadania 18.6 służące pomiarowi usprawnienia funkcjonowania jednostek organizacyjnych resortu sprawiedliwości oraz ułatwieniu obywatelom dostępu do wymiaru sprawiedliwości (m.in. liczba sądów, w których wdrożono System Wspomagania Rozpraw czy liczba sal rozpraw wyposażonych w urządzenia techniczne umożliwiające rejestrację przebiegu rozprawy sądowej). W Polsce mierniki rezultatu stosowane są stosunkowo rzadko, jest nim m.in. miernik zadania 18.5 , tj. odsetek wychowanków, którzy po opuszczeniu zakładu dla nieletnich ponownie popełnili przestępstwo (jego wartość planowana

${ }^{9}$ Roczne raporty rezultatów (fr. rapport annuel de performance, RAP) mają analogiczną strukturę jak dokumenty o charakterze planistycznym PAP, dzięki czemu możliwe jest porównywanie zaplanowanych i zrealizowanych efektów. 
na 2011 r. wynosiła 55\%, natomiast wartość wykonania w 2011 r. została oszacowana na poziomie 58,6\%). Inaczej sytuacja przedstawia się we Francji, gdzie obecnie zdecydowana większość mierników to mierniki rezultatu (stopniowe przechodzenie od mierników produktu w kierunku mierników rezultatu powinno być naturalnym kierunkiem w doskonaleniu budżetu zadaniowego).

We Francji stosuje się niespotykaną w innych krajach, które przeszły na budżetowanie zadaniowe, klasyfikację mierników, która uwzględnia punkt widzenia obywatela, podatnika bądź użytkownika usług publicznych. Mierniki ustalane z punktu widzenia obywatela (inaczej nazywane miernikami skuteczności społeczno-gospodarczej) oceniają wpływ zadań administracji rządowej na społeczeństwo, np. odsetek wykonania wydanych orzeczeń czy liczba przypadków agresji w więzieniach w przeliczeniu na 10 tys. więźniów. Mierniki z punktu widzenia podatnika (mierniki efektywności) oceniają stosunek jakości do kosztu zadania, np. liczbę spraw rozpatrywanych przez jednego sędziego, średni koszt jednej sprawy karnej czy liczbę przypadków wykorzystania wideokonferencji w sprawach karnych. Mierniki z punktu widzenia użytkownika (mierniki jakości usług) mierzą poprawę jakości świadczonych usług, np. procent sądów, w których przekraczany jest ustalony czas rozpatrzenia sprawy czy średni czas trwania jednej sprawy karnej.

Warto także zwrócić uwagę, że we Francji, inaczej niż ma to miejsce w polskim budżecie zadaniowym, nie stosuje się wskaźników mierzących poziom zadowolenia użytkowników usług publicznych. Przykładem takiego miernika w Polsce jest wskaźnik zadania 18.1, tj. odsetek obywateli pozytywnie oceniających pracę sądów (plan na 2011 r. - 34\%, wykonanie - 36\%). Jak zaznaczono w informacji o ryzyku niewykonania tego miernika, ,ryzyko związane z ewentualnym niewykonaniem miernika wynika z subiektywnego charakteru ocen dokonywanych przez respondentów"10. Wydaje się jednak, że subiektywny charakter ocen ma wpływ nie tylko na ryzyko niewykonania zaplanowanej wartości miernika, ale, co ważniejsze, ten brak obiektywizmu nie pozwala na wykorzystanie takiego wskaźnika do mierzenia realizacji celu zadania, którym jest zagwarantowanie obywatelom konstytucyjnego prawa do sądu. Można bowiem przypuszczać, że przynajmniej w niektórych przypadkach obywatel pozytywnie oceni pracę sądu, jeśli rozstrzygnięcie wydane przez ten sąd będzie dla niego korzystne.

Różnice w zakresie mierników dotyczą też samej ich liczby. Przykładowo, dla francuskiego zadania 107. Administracja penitencjarna ustanowiono sześć celów mierzonych łącznie czternastoma miernikami. Dla podobnego zadania w polskim budżecie zadaniowym (zadania 18.4. Wykonywanie kary pozbawienia wolności i tymczasowego aresztowania) ustanowiono tylko jeden cel mierzony za pomocą dwóch mierników. Ograniczona liczba celów w polskim budżecie zadaniowym już od kilku lat wynika z przepisów tzw. not budżetowych.

10 Uzasadnienia do ustawy budżetowej na 2011 r., t. II, s. 191. 
Rozporządzenie Ministra Finansów w sprawie szczegółowego sposobu, trybu i terminów opracowania materiałów do projektu ustawy budżetowej na 2012 r. (Dz. U. z 2011 r. Nr 56, poz. 290) zobowiązało dysponentów do określenia dla każdego zadania nie więcej niż dwóch celów oraz dla podzadania i działania tylko po jednym celu.

Ograniczanie liczby celów jest pożądanym kierunkiem w procesie doskonalenia budżetu zadaniowego. W Wielkiej Brytanii w 1998 r., kiedy rozpoczęto wdrażanie budżetu zadaniowego, opracowano 300 celów (wpisanych w tzw. Umowy o Świadczenia Publiczne, ang. Public Service Agreements). Z biegiem czasu liczba celów strategicznych w tym kraju znacznie zmalała. W 2000 r. było ich około 160, w 2004 r. - 110, a od 2007 r. jest ich około $30^{11}$. Taka tendencja świadczy o tym, że nabywane z biegiem czasu doświadczenie pozwala wybierać bardziej ogólne cele, jednocześnie pozostawiając dysponentom większą swobodę podejmowania decyzji zmierzających do realizacji wyznaczonych celów ${ }^{12}$. Powstaje jednak pytanie, czy limit liczby celów na poziomie zadania ustalony w Polsce już na etapie uczenia się metodologii budżetu zadaniowego nie jest zbyt niski. Wątpliwości te są o tyle uzasadnione, że na tym etapie trudno jest opracować mierniki, które będą umożliwiały dokonywanie pomiarów rezultatów administracji publicznej w syntetyczny sposób. Dzięki przyjęciu we Francji bardziej rozbudowanej koncepcji celów i mierników budżet zadaniowy pozwala lepiej zdiagnozować przyczyny niezadowalających rezultatów i podjąć określone działania, które umożliwią poprawę wyników w przyszłości.

\section{Podsumowanie}

Zastąpienie tradycyjnej klasyfikacji wydatków klasyfikacją zadaniową, której towarzyszą cele i mierniki rezultatu, stanowiło we Francji dopiero pierwszy, skądinąd bardzo istotny, etap wdrażania budżetu zadaniowego. Do pełnego wykorzystania jego możliwości konieczne stało się zidentyfikowanie obszarów, w których należy dokonać zmian, by przy wykorzystaniu tego narzędzia możliwe było przeprowadzenie niezbędnych reform. We Francji zostały one zidentyfikowane w wyniku Całościowego Przeglądu Polityk Publicznych (RGPP). W Wielkiej Brytanii takie działania podejmowane są systematycznie raz na kilka lat w formie Całościowych Przeglądów Wydatków (ang. Comprehensive Spending Review).

Wydaje się, że również w Polsce w celu zwiększenia skuteczności i efektywności wydatkowania środków publicznych potrzebna jest szersza analiza obszarów funkcjonowania państwa, w których należy dokonać konkretnych zmian. Budżet zadaniowy nie rozwiąże bowiem problemów niegospodarnego

${ }^{11}$ OCDE, La budgétisation axée sur la performance dans les pays de l'OCDE, Paris 2007, s. 214.

12 E. Ruśkowski, U. K. Zawadzka-Pąk (red.), op. cit., s. 43. 
wykorzystania pieniędzy publicznych spowodowanego wadliwymi przepisami prawa, które uniemożliwiają racjonalne wydatkowanie pieniędzy publicznych. Budżet zadaniowy jest jedynie (lub aż) narzędziem reformowania państwa. Przeprowadzenie takich analiz w obszarze francuskiej funkcji obejmującej sprawy z zakresu sprawiedliwości (fr. Justice) umożliwiło opracowanie mierników, które mierzą rzeczywiste skutki wydatkowania pieniędzy publicznych dla obywatela, podatnika i użytkownika usług publicznych.

Stosowanie niektórych mierników w polskim budżecie zadaniowym, takich jak liczba sędziów Sądu Najwyższego, poziom zadowolenia obywateli z funkcjonowania wymiaru sprawiedliwości czy terminowość rozstrzygania spraw, budzi, przynajmniej częściowo, uzasadnione wątpliwości. Francuskie doświadczenie pokazuje natomiast, że jest wiele innych, znacznie mniej kontrowersyjnych i bardziej przydatnych informacji, które można uzyskać dzięki budżetowi zadaniowe$\mathrm{mu}$. Informacje te są następnie wykorzystane, w pewnym zakresie, w procesie podejmowania decyzji o alokacji środków publicznych w kolejnych latach. 